\title{
Acute fulminant drug induced necrotizing pancreatitis in a patient with ankylosing spondylitis
}

\section{Pancreatitis necrotizante aguda fulminante secundaria a fármacos}

en un paciente con espondilitis anquilosante

\author{
P Miramontes ${ }^{1,3}$, C Montilla ${ }^{2,3}$, I Calero ${ }^{2,3}$, A Plata ${ }^{1,3}$ \\ ${ }^{1}$ Service of Internal Medicine. ${ }^{2}$ Service of Rheumatology. University Hospital of Salamanca. SACYL. Salamanca. \\ ${ }^{3}$ Biomedical research institute in Salamanca (IBSAL).
}

\section{Abstract}

Drug-induced acute necrotizing pancreatitis is a rare adverse event, although it has been reported in association with different drugs. Clinical cases of acute pancreatitis complicating treatment with anti-TNF-a such as infliximab have been exceptionally reported. We describe a patient with ankylosing spondylitis treated with etanercept who developed an acute fulminant necrotizing pancreatitis that resulted in death.

Key words: acute pancreatitis; etanercept; anti-TNF-a agents; ankylosing spondylitis.

\section{Introduction}

Drug-induced acute necrotizing pancreatitis is a rare adverse event, and it has been reported in association with different drugs ${ }^{1-3}$. Clinical cases of acute pancreatitis complicating treatment with anti-TNF-a such as infliximab have been exceptionally reported ${ }^{4}$. Contrarily, an ameliorating effect of anti-TNF-a agents on experimentally-induced acute pancreatitis in animal models has been reported ${ }^{5-8}$. We describe a patient with ankylosing spondylitis treated with etanercept who developed an acute fulminant necrotizing pancreatitis that resulted in death.

\section{Case report}

A 57-year-old man was admitted to the emergency department because of epigastric pain of one week's duration. The patient was diagnosed of ankylosing spondylitis at the age of 27 and he was treated with repeated courses of NSAIDs to which etanercept was finally added due to lack of efficacy. Six months after starting antiTNF-a therapy the disease was inactive and the patient only took indomethacin sporadically with omeprazole for gastric protection. He did not have a history of dyslipidemia or alcohol consumption. Abdominal pain was unrelated to food intake and was not accompanied by nausea, vomiting, or changes in the bowel habits. Physical examination revealed mucocutaneous jaundice and pain in the epigastrium on deep palpation without signs of peritoneal irritation. Laboratory tests on admission showed a serum bilirubin level of $6.3 \mathrm{mg} / \mathrm{dL}$ (direct bilirubin $3.6 \mathrm{mg} / \mathrm{dL}$ ), alkaline phosphatase $177 \mathrm{mg} / \mathrm{dL}$, aspartate aminotransferase $470 \mathrm{mg} / \mathrm{dL}$, and alanine aminotransferase $430 \mathrm{mg} / \mathrm{dL}$. The serum lipid profile, ions and amylase in serum and urine were within normal ranges. The abdominal ultrasound and computed tomography (CT) scan were unrevealing. An upper gastrointestinal en-

\section{Resumen}

La pancreatitis aguda necrotizante inducida por medicamentos es un efecto adverso raro, y ha sido descrito en asociación con diferentes fármacos. Los casos clínicos de pancreatitis aguda secundarias a tratamiento con anti-TNF-a como el infliximab se han descrito de forma excepcional. Por el contrario, se ha informado de un efecto de mejora de los agentes anti-TNF-a en la pancreatitis aguda inducida experimentalmente en modelos animales. Describimos un paciente con espondilitis anquilosante tratado con etanercept que desarrolló una pancreatitis necrotizante aguda fulminante que resultó en el fallecimiento del paciente.

Palabras clave. Pancreatitis aguda. Etanercept. Agentes anti-TNF-a. Espondilitis anquilosante

doscopy was normal. Treatment with etanercept was stopped and the patient was given ketorolac for pain relief and pantoprazole. Seven days after admission, the same pattern of abdominal pain persisted and became more severe. The serum amylase level was 2013 mg/ $\mathrm{dL}$ and urine amylase 29,000 mg/dL. Abdominal ultrasound revealed an enlarged pancreatic gland with illdefined borders. An urgent CT scanning showed suggestive signs of necrotizing pancreatitis (Figure 1). Serological tests for infection with hepatitis $A$ virus (HAV), hepatitis $B$ virus (HBV), hepatitis $\mathrm{C}$ virus (HCV), cytomegalovirus and EpsteinBarr virus were negative. Antinuclear antibodies, anti-LKM-1 and antimitochondrial antibodies were also negative. A magnetic resonance cholangiography to exclude microlithiasis was not performed because the patient was wearing a knee prosthesis. An exploratory laparotomy was performed, revealing a markedly enlarged pancreas of inflammatory aspect spreading towards the duodenum and the common bile duct. The histopathologic study showed steatonecrosis

Figure 1. The abdominal CT scan showed an increase in the pancreatic volume, with areas of necrosis and peripancreatic fluid, without evidence of cholelithiasis or pancreatic calcifications

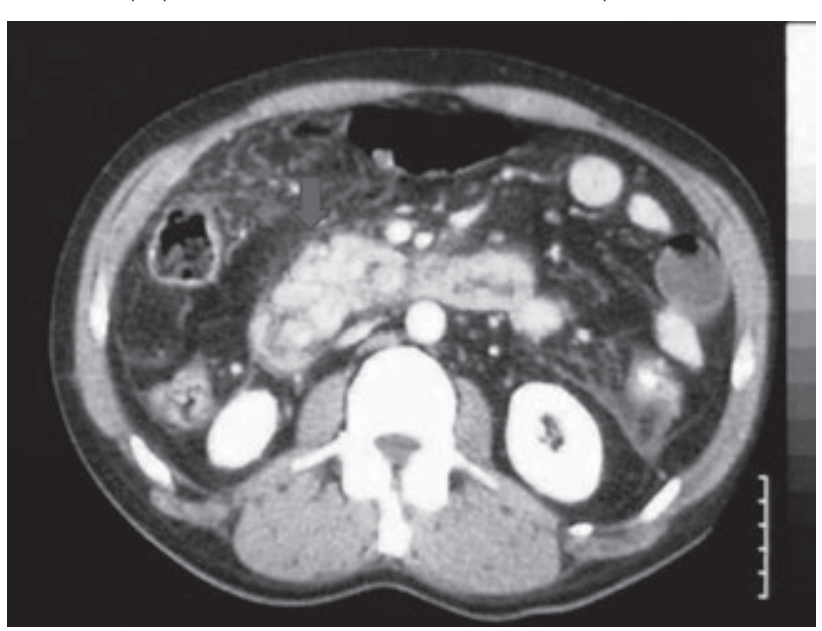


Figure 2. Histopathological examination showing steatonecrosis with abundant lymphocytic and plasmocytic infiltration

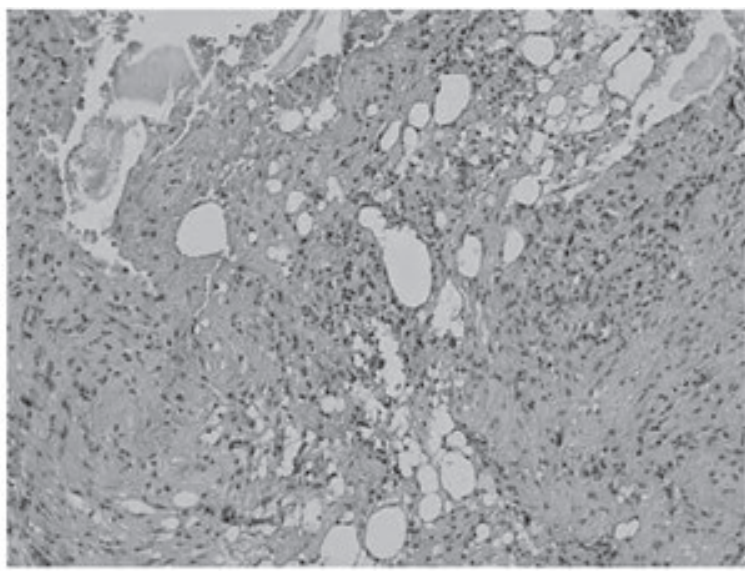

with abundant lymphocytic and plasmocytic infiltrate and minimal fibrosis (Figure 2). The patient was transferred to the intensive care unit (ICU) and died 48 hours after ICU admission due to multiorgan failure. After reasonably excluding common causes of acute pancreatitis, such as biliary lithiasis, alcoholism or hypertriglyceridemia, the final diagnosis was drug-induced pancreatitis.

\section{Discussion}

Acute pancreatitis typically presents as an acute inflammation of the pancreas that may or may not involve the surrounding tissues. Gallstones and heavy alcohol use are major causes of this condition. Other common causes include trauma, pancreatic tumors, surgery, hypertriglyceridemia, endoscopic retrograde cholangiopancreatography and hyperparathyroidism 1 . Drug-induced acute pancreatitis ranges from between 0.1 and $2 \%{ }^{9}$. Different classifications of drugs commonly associated with pancreatitis have been proposed. Using criteria based on the presence of a rechallenge, latency, and the number of the cases reports (Table 1), a classification system "based on the evidence" was provided². Table 2 shows the medications from the published case reports with the "most evidence" of causing acute pancreatitis². There is no clear mechanism by which drugs cause pancreatitis, although they appear to induce pancreatitis by direct or indirect effects or a combination of both. Direct effects include toxic effects (diuretics, steroids) or hypersensitivity reactions (azathioprine, aminosalicylates), while indirect mechanisms consist of ischemia (diuretics, azathioprine) or intravascular thrombosis (steroids)' A number of drugs used to treat rheumatologic diseases can trigger acute pancreatitis. Etanercept binds specifically to tumor necrosis factor (TNF) and blocks its interaction with cell surface TNF receptors. Our patient, however, also received other medications described to induce acute pancreatitis, such as indomethacin and omeprazole prior to the episode of acute pancreatitis, and ketorolac together with pantoprazole during hospital admission. Although the duration of treatment with etanercept of 6 months may be too long for a causeeffect relationship, the implication of etanercept as the causative drug of acute pancreatitis cannot be excluded. In conclusion, we present a patient who developed a fulminant acute necrotizing pancreatitis and had a fatal outcome, plausibly
Table 1. Classification of drug induced pancreatitis.

Class la drugs

At least 1 case report with positive rechallenge, excluding all other causes, such as alcohol, hypertriglyceridemia, gallstones, and other drugs.

\section{Class Ib drugs}

At least 1 case report with positive rechallenge; however, other causes, such as alcohol, hypertriglyceridemia, gallstones, and other drugs were not ruled out.

\section{Class II drugs}

At least 4 cases in the literature. Consistent latency ( $75 \%$ of cases).

\section{Class III drugs}

At least 2 cases in the literature. No consistent latency among cases. No rechallenge.

\section{Class IV drugs}

Drugs not fitting into the earlier-described classes, single case report published in medical literature, without rechallenge.

Table 2. Summary of drug-induced acute pancreatitis

\section{Class la}

Azodisalicylate, bezafibrate, cannabis, carbimazole, codeine, cytosine, arabinoside, dapsone, enalapril, furosemide, isoniazid, mesalamine, metronidazole, pentamidine, pravastatin, procainamide, pyritonol, simvastatin, stibogluconate, sulfamethoxazole, sulindac, tetracycline, valproic acid

\section{Class Ib}

All trans-retinoic acid, amiodarone, azathioprine, clomiphene, dexamethasone, ifosfamide, lamivudine, losartan, lynesterol/methoxyethinylestradiol, 6-MP, meglumine, methimazole, nelfinavir, norethindronate/mestranol, omeprazole, premarin, sulfamethazole, trimethoprimsulfamethazole

Class II

Acetaminophen, chlorthiazide, clozapine, DDI, erythromycin, estrogen, L-asparaginase, pegasparagase, propofol, tamoxifen

associated with drug-induced pancreatitis. Due to the rarity of this adverse event doctors should pay close attention to patients taking this kind of drugs in which a complaint of abdominal pain lasting for several days with no apparent cause may require a prompt referral for medical consultation.

Acknowledgements: The authors thank Marta Pulido, MD, for editing the manuscript.

\section{References}

1. Eltookhy A, Pearson NL (2006) Drug-induced pancreatitis. Canadian Pharmacists Journal (CPJ) 139:58-60.

2. Scott Tenner. Drug induced acute pancreatitis: Does it exist? World J Gastroenterol. 2014 November 28; 20(44):16529-16534.

3. Biour M, Daoud H, Ben Salem C (2005) Drug-induced pancreatitis. Second edition of the bibliographic database of pancreatitis related to drugs. [Article in French]. Gastroenterol Clin Biol 29:353-359.

4. Fefferman DS, Alsahli M, Lodhavia PJ, Shah SA, Farrell RJ (2001) Re: Triantafillidis et al.--Acute idiopathic pancreatitis complicating active Crohn's disease: favorable response to infliximab treatment. [Letter]. Am J Gastroenterol 96;2510-2511.

5. Oruc N, Ozutemiz A0, Yukselen V, Nart D, Celik HA, Yuce G, Batur Y (2004) Infliximab: a new therapeutic agent in acute pancreatitis? Pancreas 28;e1-e8.

6. Yilmaz M, Topsakal S, Herek 0, Ozmen 0, Sahinduran S, Buyukoglu T, Yonetci N (2009) Effects of etanercept on sodium taurocholate-induced acute pancreatitis in rats. Transl Res 154;241-249.

7. Malleo G, Mazzon E, Genovese T, Di Paola R, Muià C, Centorrino T, Siriwardena AK, Cuzzocrea S (2007) Etanercept attenuates the development of cerulein-induced acute pancreatitis in mice: a comparison with TNF-alpha genetic deletion. Shock 27:542-551.

8. Yilmaz M, Tekekoglu S, Herek O, Ozmen O, Sahinduran S, Buyukoglu T (2010) Ameliorative effect of adalimumab on experimentally induced acute pancreatitis in rats. Pancreas 39:1238-1242.

9. Nitsche CJ, Jamieson N, Lerch MM, Mayerle JV (2010) Drug induced pancreatitis. Best Pract Res Clin Gastroenterol 24:143-155. 